\title{
KAZNET: ANALYSIS OF ART COMMUNITIES
}

\author{
Shaidulina Darya \\ tonythefizz@hotmail.com \\ Institute of Philosophy, Political Science and Religious Studies CS MES RK \\ (Almaty, Kazakhstan)
}

Шайдулина Дарья

tonythefizz@hotmail.com

Институт философии, политологии и религиоведения КН МОН РК

(Алматы, Казахстан)

\begin{abstract}
The article is devoted to the study of Kazakhstani independent art platforms on the Internet. As the objects of research, the author selected two leading artistic resources of the Kaznet, dedicated to domestic contemporary art - Astral Nomads and Qazart, the analysis of which made it possible to reveal the significance of digital technologies and the virtual world for the modern culture of Kazakhstan. The platforms emerged as a response to problems of material destruction threaten art objects and aspiration for promotion of Kazakhstani contemporary art. In current conditions, we are able to trace the tendency of increasing involvement into virtuality.
\end{abstract}

Key words: virtuality, digitalization, postmodernity, contemporary art, Kaznet, art space.

\section{Introduction}

The coronavirus pandemic has strengthened the orientation of modern society towards an activity transition to the virtual digital space, which in the current stressful and depressive conditions is becoming almost the only field for solving most social, communicational, business, educational and cultural problems. The role and significance of multidirectional Internet platforms, particularly, art projects, as the only ones available for visiting in a difficult epidemiological situation, have grown unprecedentedly.

In Kazakhstan, long before the onset of the COVID-19 pandemic, the issue of transition to a digital society became one of the highest priorities. To implement the solution to this problem, a comprehensive program "Digital Kazakhstan" was developed and approved by the Decree of the Government of the Republic of Kazakhstan № 827 dated December 12, 2017. The purpose of the program is to improve the living standards of Kazakhstanis by means of modern digital technologies using [1].

\footnotetext{
* This research was funded by the SC MES RK (№OR11465461 "The study of culture and values of the society in the context of sustainable development strategy of Kazakhstan").
} 
According to the multi-vector program "Digital Kazakhstan", modernization work is focused on five main points [2]:

1. Digitalization of economic sectors.

2. Transition to a digital state.

3. Implementation of the Digital Silk Road.

4. Development of human capital.

5. Creation of an innovation ecosystem.

It should be noted that in the perspective of the successful implementation of program tasks, there will be a tendency towards greater involvement in cyberspace and an increase in the activity of citizens in the virtual digital environment, including its art segment.

By now, the World Wide Web has become a space in which a user, regardless of his volume of computer-technical knowledge and skills, has a chance to realize his creative ambitions, satisfy communication needs and form a personal brand. The ways of mastering the cyberworld are diverse: promoting users' own pages in popular social networks, maintaining independent stand-alone blogs, shooting vlogs, organizing large thematic platforms. All these types of online activities are successfully carried out by numerous world artistic figures.

In the Kazakhstani segment of the Internet the field of art is represented by creative materials published on personal pages in social networks, portals of state museums, commercially oriented websites of photo studios and art galleries, as well as several large independent art platforms, two of which appear as the objects of this research. They are digital projects Astral Nomads by Yulia Sorokina and Qazart by Vladislav Sludsky.

\section{Methodology}

During the researching we used a philosophical and culturological methodological toolkit, which allows us to deeply analyze the phenomenon of art portals of the Kazakhstani segment of the Internet: the prerequisites of their genesis, features of content formation, goal-setting and formulation of the project's mission.

The historical method made it possible to find the reasons that inspired the creation of domestic art platforms, to track the processes of content formation and the dynamics of the activity of web resources. We focused on the method of content analysis, owing to which processing of the graphical and textual informational array of the studied web portals was carried out. The methodological complex included a systemic method, through which the studied phenomenon was considered in its holistic nature and the role of its structural elements was revealed; dialectical method that helps to reveal the essence of dynamic processes; the method of comparative analysis using which the essential differences between the classical and non-classical cultural paradigms were revealed.

\section{Astral Nomads}

A unique cultural Internet project Astral Nomads («Звездные кочевники») arose as a reaction to a need to preserve and distribute the creative heritage of not only modern 
Kazakhstani, but also Central Asian artists in general who have passed away. The founder of the platform, domestic independent art curator Yulia Sorokina, during her professional career, faced with the difficulties of place conducting and maintaining the functioning of institutions with a traditional material form of existence (museums, galleries, etc.), came to the conclusion that these difficulties can be compensated or, moreover, eliminated through the process of transition to the virtual digital space. Among the problems of storage facilities existing in the material world, Sorokina singles out the followings [3]:

1. Fragmentation, in the conditions of which it is impossible to assemble an integral system of information and artifacts related to the life and work of an artist, in one institution. Often, their separate storage or exposition is carried out: works of art belong to the museum fund, text sources to the libraries, personal belongings may remain the property of an artist's heirs. This problem, according to Yulia Sorokina, interferes with a holistic understanding of artist's personality and, therefore, leads to errors and misconceptions in the reading and interpretation of his works.

2. Threat to physical existence. Many factors can lead to disappearance of a material art object: an institution that stores and exhibits a creative heritage may be undergo closure and demolition with subsequent loss or damage to the collection; failure in realization of restoration work, deterioration of storage conditions also inevitably lead to fatal deformations and destruction of works. Yulia Sorokina emphasizes that at the moment, in the conditions of absence of an author's heirs or their indifference to his cultural heritage, exactly such a fate with inevitable subsequent oblivion of the creator himself awaits an artistic work.

In the current conditions of Kazakhstani society, an obtainable solution to these problems, the curator believes, is an appeal to digital technologies and the ways of duplication of material things in the virtual space: "Online-field has some wonderful qualities and if we distract ourselves from the outdated paradigm of an art-object which is possible to exist only in physical form, we become able to imagine an existence of an artist in the virtual space of an on-line archive and his reincarnation of a certain kind in this cosmos"'[ibid.].

Considering cyberspace as an alternative to the physical one and assessing the potential of the opportunities it offers for the art community, Yulia Sorokina highlights the following positive properties of virtuality [ibid.]:

1. An ability to create on one platform an ordered system with a multi-volume information base: creative works, documents with biographical information, critical notes and other materials that allow a comprehensive disclosure of an artist's personality - as a creator and as a person. As stated above, such a systemic unity is difficult to implement in the material space due to various reasons, among which the most common is finding of an author's legacy in the ownership of several persons and placement in various institutions.

2. The digital space has "an ability to freely model the necessary information" [ibid.], which contributes to the establishment of a special kind of communication, dialogue between a viewer, creatively perceiving a work of art, and a deceased artist.

3. Adequacy of using exceptionally digital copies of material objects that compose the biographical, ideological and creative paradigm of an author, which helps avoid conflicts with the owners of a physical artifact. 
4. High speed and absence of spatial restrictions for distribution of information these qualities of the World Wide Web are emphasized by the curator Yulia Sorokina as especially valuable.

In our opinion, the second advantage of using digital technologies noted by Sorokina is not an exclusive feature of the virtual environment. The processes of interpretation of works of art, acquaintance with a personality of an artist, forming a dialogical connection between a viewer and an author, also take place in material reality - this is an integral part of perception process, reading of an art object, and for such kind of communication the nature of the object - digital or physical - is not important.

The considered above problems of organizing an archive of creative heritage in material reality and the undoubted advantages of maintaining corresponding project in virtuality served curator Yulia Sorokina as the reason and basis for the creation of the Astral Nomads digital platform, the mission of which is to preserve, systematize and popularize the art of Central Asian artists.

As the name of the Internet project, the founder chose the title of Kazakhstani artist Sergei Maslov's novel Astral Nomads, dedicated to the life of his colleagues and contemporaries [4], and the epigraph of the site became Maslov's quotation: "We have not lost anything. We are the astral nomads, wandering through interstellar space, visiting unfamiliar planets is a thrill for us" [5].

To date, the digital archive contains works by contemporary Kazakh, Uzbek and Kyrgyz artists: Vyacheslav Akhunov, Gamal Bokonbaev, Rustam Khalfin, Sergei Maslov, Ulan Dzhaparov and Yuri Dvinyaninov. Each of them has a personal page with biographical notes and artworks provided with detailed information. The platform interface assumes free commenting and admissibility of discussion. However, unfortunately, we note that visitors of the resource use this opportunity extremely rarely and despite the active status of the website, some of the last comments are dated 2013. Thereby, the communicative engagement of the platform audience is very low and cannot be analyzed. It should be noted that the digital art archive has two language versions: Russian and English. The last one makes it possible to significantly expand the audience pool and make contemporary Central Asian art available to the Internet users from all over the world, and not be limited to a certain network segment.

As we were studying the Astral Nomads online archive collection, we found that it has digital versions of artwork from a period of creative practice beginning in the 1980s and continuing for the next three decades. Each of the art objects of the digital exposition is a virtual duplicate of the original material work, which makes it possible to characterize the entire collection of Astral Nomads" works as "art on the net".

The collection of creative works of Astral Nomads web-archive cannot be fully attributed to the media art direction, for which not only the availability of a digital exposure option is fundamental, but also genesis in the digital environment, in particular the Internet space, with the means of computer technology or a mixture of traditional and innovative techniques. The artistic works of the authors of the Astral Nomads project were created as material objects in material environment, and then they were digitized and placed in virtual reality. Meanwhile, it should be noted that the platform's archive also contains media works (video files), the reproduction and exposure of which are 
possible only with the help of computer technologies. Their primarily immaterial nature and artistic technique make it possible to classify the works as new media art, video art, but the number of these works is very small and they are an exception among the vast majority of art on the net works.

Returning to the question of multiplication of the art objects of the Astral Nomads, which they undergo in the process of digitalization, we assume the possibility of its interpretation through the prism of two philosophical and cultural paradigms - modern and postmodern.

The postmodern approach to understanding the duplication of a tangible, physical art object in virtual-digital environment does not imply the creation of a copy, but another original, endowed with new existential parameters. Thereby, a virtual art object is a digital cast of a material original; it is an independent and separate work with preservation of authorship. For its perception, the properties and the fact of existence of the material work - a generative point, are not important, such a new object is a unique and complete work of art.

In contrast to this viewpoint, the modern approach, which is followed by the founder and head of the Astral Nomads project, Yulia Sorokina, retains the status of an original work for a primary material art object and evaluates its virtual-digital version as a copy, an intangible duplicate created with the help of innovative technologies. In this case, cyberspace performs the function of a digital exposition platform, but not a generative environment for art objects, which is essential characteristic of virtuality in the postmodern paradigm.

The mission of the Astral Nomads project is to preserve works of art, pass them on to the future generations and popularize them in the world art community. Consequently, in accordance with these goals, the traditional, modernist approach to the perception of this digital collection and its exhibition environment is more correct.

The virtual digital art project Astral Nomads, being one of the few pioneers of this direction in the domestic cyberspace, was able to become one of the most famous cultural platforms in the Kazakhstani segment of the World Wide Web and retain the status of a significant archive of contemporary Central Asian art, regardless of frozen audience activity at the present time.

\section{Qazart}

In 2019, in the Kazakhstani segment of the World Wide Web, with the support of the Eurasian Cultural Alliance, the Qazart platform appeared, dedicated to contemporary Kazakhstani art and cultural figures and presented in the media as the first Kaznet portal of this kind. The founder of the art platform Vladislav Sludsky, as a prerequisite for the initiation of such a project, indicated the absence of an orderly, systematized activity for contemporary Kazakhstani art archiving [6].

In addition to the intention to solve the problem of concentration and ordering of the array of creative works of modern Kazakhstani artists on one platform, the curator accentuated a number of the following goals that make up the mission of the digital project: representation of the current cultural state of Kazakhstan in virtuality, popular- 
ization of Kazakhstani contemporary art abroad and the formation of large viewership, support for collecting activities and empowering artists in art sales area.

It is important to note that Vladislav Sludsky emphasizes that the commercial component of his platform is not fundamental and does not act as a dominant interest. For him Qazart is a harmonious multi-vector project: "I do not consider it as an exceptionally commercial product, or exceptionally educational. This is a synergy of academic interest of foreign colleagues in Kazakhstani contemporary art with the ability to purchase particular works for private and public collections" [ibid.].

This curator's approach to characterizing the art platform is postmodern in its essence and exactly corresponds to the nature of cyberspace. The impetus for the creation of the portal was a very specific and unambiguous idea of archiving art in virtuality. However, as the project was developing, other goals appeared and they did not become secondary in importance, but expanded the original concept. Thereby, the commercial component is not regarded as low-rated pragmatic element in comparison with the aesthetic and educational functions of this web resource; its presence does not transform a digital gallery into an online store, within the boundaries of which exceptionally market relations take place. The Qazart project combines several complementary functions - research, aesthetic, educational and commercial, each of which is equal and forms an integral multifaceted network resource.

The non-classical nature of the way cyber exposition content is formed is emphasized by the principle manifested in a short welcome text published on the Qazart platform: the process of selecting artworks for a project is always aimed at maintaining diversity and providing an opportunity for self-expression and presentation to the audience of artists of different generations and backgrounds [7]. The aesthetic or, possibly, potential educational value of a work is determined by the curator(s) of the art platform, it is a decisive factor in selection, and the level of fame of the author or the popularity of the direction in which the artist works have no influence on selection process. The dichotomy of mass and elite culture disappears; kitsch, naive and camp are equalized with the high art. The works of a recognized art figure and an unknown creative enthusiast are located in one expositional cyber room.

The genre and visual-technical diversification of the content of the Qazart platform is a postmodern eclecticism, embracing creative directions from easel painting to bricolage. A digital online gallery is able to accommodate an almost infinite number of works belonging to the most diverse and unexpected in their neighborhood themes, forms and techniques, and place them under genre headings - web pages, meanwhile forming a holistic and harmonious art space.

As an illustration that perfectly reflects such a structural and organizational essence of the Qazart platform, we would like to cite a series of collage-photo prints by artist Bakhyt Bubikanova "Renaissance Kazakheliyan barocco" - Renaissance of the Kazakh El baroque, also presented in the virtual digital collection of the project [8]. The ironic work of Bubikanova, its very name is a postmodern mixture and layering of elements of completely different artistic styles, temporal phases and historical and cultural areas. At the same time, placing this material work in the cyber gallery leads it to multiplication, generation in a digital form - this is how a work exists in two spaces, 
real and virtual, likewise the idea of the resource is inspired by the world of physical objects and continues to develop in the digital world.

Along with the postmodern features of the Qazart portal, we can also find elements that are inherent to the classical cultural paradigm, and they consist in the approach to the process of interpreting of creative works.

The perception and reading of an art object in modern and postmodern cultures have a fundamental difference that determines a figure and creative role of a subject. The classical understanding of the perception of a work of art consist in a proposition that an author puts into his work a certain idea that a viewer must comprehend. Consequently, the author's intention is the only correct interpretation that the audience can approximate with more or less success. In contrast to this viewpoint, in the context of postmodern culture, which strives to destroy the concept of a single truth and manifests an infinite plurality of meanings, an artistic work becomes independent and each recipient is presented as a new generator of the meaning of work by the principle of "author's death".

The Qazart platform proposes its visitors to adhere to the classical principle of interpreting works of art, which follows from the peculiarity of the presentation of collection objects on their web pages: from a large number of exhibited art works, some are chosen as the favorites of the project curator (Curator's Choice) and they are provided with an information block extended with a special note, while the works that are not included in the list of the selected artifacts are accompanied only by a brief material characteristic.

These notes, additionally included in the informational block of selected works, announce the visitors of the virtual gallery the correct interpretation of the work, reveal the author's intention, preventing erroneous interpretation by the viewer.

For example, the work "Pery" by Bakhyt Bubikanova is accompanied by the following detailed commentary, which does not leave the viewer the opportunity to supplement the work with his own thoughts and experiences: "This digital collage is a self-portrait of the artist Bakhyt "Baha" Bubikanova composed of images of newborn babies and defragmented parts of the military men that disguise the identity of the central figure. The role of women and marriage in Kazakhstan's patriarchal society implies numerous traditional requirements and taboos, such as childbearing. Bubikanova uncovers her subconscious fears of the pressure that comes from her family members, her close surroundings, and the society at large"[9].

In our opinion, the decision to accompany certain works of the collection with the notes containing the full disclosure of the idea of the work, deciphering of its symbolism is caused by the curator's desire to provide confidence that the artist's intention will be correctly interpreted by a viewer and a dialogue will arise between them, which in turn will play the role of an immersive means. This is a fairly straightforward way to establish communication between an author and a recipient, but it is effective in order to increase attention to the work and helps a viewer to focus more easily and quickly on key points.

It is important to note that communication with the audience is a significant process for the Qazart project, which positions itself more than a network art archive, a 
server for accumulation of digitalized art objects. The management of the platform has set an informative and educational goals, popularization and promotion of domestic contemporary art abroad. The comments of the curator to the selected works considered above not only contribute to the comprehension of the semantic contents by all users, but also help representatives of the foreign audience to learn about the peculiarities of Kazakhstani society, history and art.

\section{Conclusion}

The art segment of the Kaznet is an extremely narrow space with an inactive audience, which stands at the initial stages of formation. Meanwhile, the island-like specialized web platforms existing in it, created and supervised by professionals belonging to the field of creativity and arts, are stable and have clearly formulated goals and a transparently expressed attitude to the phenomenon of virtuality and innovative technological toolkit of our time.

The study of significant independent authors' platforms belonged to the artistic direction of Kazakhstani cyberspace showed that the prerequisites that inspired the creation of these digital resources are similar and consist in followings:

1. The need to create an archive, backup storage of works of art, which would prevent their irreversible disappearance.

2. The need to order and centralize the array of works of Kazakhstani contemporary art.

3. The will to popularize the activities of domestic artists and contribute to the promotion of Kazakhstani culture and art, reaching a large audience.

The best solution chosen to satisfy these needs, in actual circumstances, was the appeal to the virtual digital space, which provides users with unlimited storage and communication opportunities, and also has some significant advantages over the organization of such projects in material reality:

1. Digitalized art objects do not require special storage conditions, restoration work, and a certain size of area that can accommodate the entire exposition and avoid damage. A digital work can be reproduced and stored on virtual servers in the form of digital copies for an infinite number of times. These properties of intangible objects allow to protect works of art from the danger of complete loss, which can threaten physical objects. Thereby, in a situation of destruction, loss, deformation or other negative impact on an object, its virtual image will exist, exactly repeating the material original, and it will allow to preserve the authentic artistic work for the cultural fund and future generations, albeit in the form of an intangible moulage.

2. A web resource, in contrast to a material analogue, has the property of unlimited archival, accumulative possibilities - a virtual digital platform is able to store any amount of necessary digitalized, electronic information, which will allow to form the most complete representation of the exhibited objects, their authors and cultural and historical context. Concentration of all available information in one open resource makes it easier for users to search for information of interest and forms a holistic system. In addition to that, access to such a database is possible from anywhere in the 
world, on condition of availability of the proper technical equipment, which is impossible for non-digital archives that require a physical presence.

3. The virtual digital space is devoid of the limitations inherent in the real space - territorial and geographical boundaries. Moreover, the Internet environment allows one to overcome intercultural barriers. The speed of dissemination of information online and the planetary coverage of a potential audience make virtuality an excellent field for the promotion of culture and art. The art platforms Astral Nomads and Qazart discussed in our research have versions of the interfaces in English, a modern lingua franca, which contributes to communicative efficiency and access to the global network space from a narrow local segment of the World Wide Web.

The founders of the virtual art platforms primarily approach the digital environment from a pragmatic position. The online space excite interest for its enormous possibilities of archiving and exhibiting, solving information and communication problems. The process of digitalization in this case is the process of preserving works of art, and the creation of a digital gallery or archive is an addition to the management of an institution existing in objective reality, its duplication in a qualitatively new environment.

In 2020, the IADA art portal (International Art Development Association), which supports and contributes to the promotion of Central Asian and, in particular, Kazakhstani contemporary art, published materials from the digital exhibition Cybernomadism curated by Kazakhstani artist Anvar Musrepov. In his introductory remarks to Cybernomadism, the organizer expresses the attitude of the artistic collective to the very phenomena of virtuality and the digital world: "An exhibition in the digital space, as a collection of works freed from decay processes, can be imagined as a time capsule. We are sending this message into the future from the present, in which we are in quarantine, wondering what the world will be like after COVID-19. Thinking about the future and surfing the culture of the mainstream, every time we return to dystopia as a crisis of Western narratives of the future" [10].

We see that for representatives of Kazakhstani contemporary art, the virtual digital world is valuable as an agent of communication and preservation of cultural heritage for future generations. This is a new form of existence of an author and his works in space and time, which seems to be reliably protected from the destruction of the material world.

Digital innovation processes, which have rapidly embraced all spheres of human life, have had a positive impact on the domestic contemporary art: there is an opportunity for the development of international artistic discourse, a new source of inspiration for artists who are open to creative experiments. The positive interest in the cyber world of curators, artists and art enthusiasts testifies to the fact that this area of the Kaznet is striving for development and strengthening.

\section{List of references}

1. О программе. 2017. [Electronic resource]. URL: https://digitalkz.kz/o-programme/ (accessed 12.07.2021). 
2. Пять направлений Программы. 2017. [Electronic resource]. URL: https://digitalkz. kz/napravleniya-programmy/ (accessed 12.07.2021).

3. Сорокина Ю. Художник как архив. 2012. [Electronic resource]. URL: http://zhurnal-prostor.kz/assets/files/2012/2012-6/2012-6-16.pdf (accessed 15.07.2021).

4. Сорокина Ю. О проекте AN. 2013. [Electronic resource]. URL: http://astralnomads. net/about/?lang=ru (accessed 16.07.2021).

5. Маслов С. Звездные кочевники. 2002. [Electronic resource]. URL: http://astralnomads.net/artleaflet/?lang=ru (accessed 16.07.2021).

6. Buro247.kz. В Алматы запустился сайт о современных казахстанских художниках. 2019. [Electronic resource]. URL: https://www.buro247.kz/culture/art/v-kazakhstane-zapustilas-platforma-kaz-iskusstva.html (accessed 23.07.2021).

7. Qazart. About. 2019. [Electronic resource]. URL: https://www.qazart.com/about (accessed 23.07.2021).

8. Bubikanova B. Renaissance Kazakheliyan barocco. 2014. [Electronic resource]. URL: https:/www.qazart.com/product-page/renaissance-kazakheliyan-barocco-bakhyt-bubikanova (accessed 24.07.2021).

9. Bubikanova B. Pery. 2012-2013. [Electronic resource]. URL: https://www.qazart.com/ product-page/pery-bakhyt-bubikanova (accessed 24.07.2021).

10. Cybernomadism. 2020. [Electronic resource]. URL: https://iada-art.org/cybernomadism-ru (accessed 25.07.2021).

\section{Transliteration}

1. O programme [About Program]. 2017. [Electronic resource]. URL: https://digitalkz. kz/o-programme/ (accessed 12.07.2021).

2. Pyat' napravlenij Programmy [The Five Directions of the Program]. 2017. [Electronic resource]. URL: https://digitalkz.kz/napravleniya-programmy/ (accessed 12.07.2021).

3. Sorokina Yu. Hudozhnik kak arhiv [Artist as Archive]. 2012. [Electronic resource]. URL: http://zhurnal-prostor.kz/assets/files/2012/2012-6/2012-6-16.pdf (accessed 15.07.2021).

4. Sorokina Yu. O proekte AN [About AN Project]. 2013. [Electronic resource]. URL: http://astralnomads.net/about/?lang=ru (accessed 16.07.2021).

5. Maslov S. Zvezdnyye kochevniki [Astral Nomads]. 2002. [Electronic resource]. URL: http://astralnomads.net/artleaflet/?lang=ru (accessed 16.07.2021).

6. Buro247.kz. V Almaty zapustilsya sajt o sovremennyh kazahstanskih hudozhnikah [Website About Contemporary Kazakhstani Artists Launched in Almaty]. 2019. [Electronic resource]. URL: https://www.buro247.kz/culture/art/v-kazakhstane-zapustilas-platforma-kaz-iskusstva.html (accessed 23.07.2021).

7. Qazart. 2019. 'About'. [Electronic resource]. URL: https://www.qazart.com/about (accessed 23.07.2021).

8. Bubikanova B. Renaissance Kazakheliyan barocco. 2014. [Electronic resource]. URL: https:/www.qazart.com/product-page/renaissance-kazakheliyan-barocco-bakhyt-bubikanova (accessed 24.07.2021).

9. Bubikanova B. Pery. 2012-2013. [Electronic resource]. URL: https:/www.qazart.com/ product-page/pery-bakhyt-bubikanova (accessed 24.07.2021).

10. Cybernomadism. 2020. [Electronic resource]. URL: https://iada-art.org/cybernomadism-ru (accessed 25.07.2021). 


\section{Шайдулина Д.Р.}

Казнет: өнер қоғамдастығына талдау

Аңдатnа. Мақала интернеттегі қазақстандық тәуелсіз өнер платформаларын зерттеуге арналған. Зерттеу объектісі ретінде автор казнеттің отандық заманауи өнерге арналған екі жетекші көркемдік ресурсын - «Жұлдызды көшпенділер» мен Qazart алып, олардың қызметін талдау арқылы қазіргі Қазақстанның мәдениеті үшін цифрлық технологиялар мен виртуалды әлемнің маңыздылығын ашуға мүмкіндік берді. Бұл платформалар өнер объектілеріне қауіп төндіретін материалдық жойылу мәселелері мен қазақстандық заманауи өнерді насихаттау ұмтылысына жауап ретінде пайда болды. Қазіргі жағдайда виртуалды әлемге деген қызығушылықтың арту үрдісін байқай аламыз.

Tүйін сөздер: виртуалдылық, цифрландыру, постмодерн, заманауи өнер, казнет, өнер кеңістігі.

\section{Шайдулина Д.Р. \\ Казнет: анализ арт-сообществ}

Аннотация. Статья посвящена исследованию казахстанских независимых артплатформ в сети Интернет. В качестве объектов исследования автором были выбраны два ведущих художественных ресурса казнета, посвященных отечественному современному искусству - «Звездные кочевники» и Qazart, анализ деятельности которых позволил выявить значимость цифровых технологий и виртуального мира для современной культуры Казахстана. Данные платформы возникли как ответ на проблемы материального разрушения, грозящего арт-объектам и стремления к продвижению казахстанского современного искусства. В актуальных условиях мы можем наблюдать тенденцию к возрастающему вовлечению в виртуальность.

Ключевые слова: виртуальность, дигитализация, постмодерн, современное искусство, казнет, арт-пространства. 